\title{
AUTOMOTIVE SHOCK ABSORBERS' APPLICABILITY FOR DAMPING RESONANT OSCILLATIONS IN CONSTRUCTION MACHINES
}

\author{
Sergei Repin ${ }^{1}$, Roman Litvin ${ }^{1 *}$, Victor Kuzmichev ${ }^{2}$, Ivan Vorontsov ${ }^{1}$ \\ ${ }^{1}$ Saint Petersburg State University of Architecture and Civil Engineering \\ Vtoraja Krasnoarmeyskaya st., 4, Saint Petersburg, Russia \\ ${ }^{2}$ Peter the Great St.Petersburg Polytechnic University \\ Polytechnicheskaya, 29, Saint Petersburg, Russia \\ *Corresponding author: roman.Itv@mail.ru
}

\begin{abstract}
Introduction: Many vibration transport and technological machines (VTTM) such as conveyors, screens, crushers, etc. operate in a high-frequency mode, or above resonance. Resonance occurs during machine start and slowdown, resulting in sharply rising values of the amplitude and velocity of oscillations. Resonance affects VTTMs adversely due to increased dynamic loads reducing machinery operating life and reliability and causing the noise. Purpose of the study: We aim to provide a theoretical substantiation for the possibility to apply automotive shock absorbers to VTTM oscillatory process control and develop an example of practical implementation for such a device. Methods: The method of controlling oscillatory processes in VTTMs lies in the use of dual-mode shock absorbers. In the operating mode, shock absorbers offer minimum resistance to motion. In the resonance mode, resistance increases, therefore, the amplitude decreases to a predetermined value. Results: We simulate the VTTM oscillatory process in order to determine the characteristics of a damping device, which ensures the suppression of resonant oscillations but does not affect the vibration operating process. We propose a new technical device implementing the required oscillation characteristics. The device is made in the form of a hydro-pneumatic shock absorber, similar to automotive shock absorbers in terms of design. Such a design makes it possible to offer slight damping of the machine's useful (operating) vibration, but, at the same time, damping increases significantly in the case of resonant amplitudes. The originality of our study lies in the development of a new type of hydraulic shock absorber, for which a utility model patent has been obtained. The scientific novelty of the study is in the mathematical description of oscillation damping with the new shock absorber, in the development of software for oscillatory process analysis according to the developed mathematical model, and in the results of computer simulation for shock absorber operation.
\end{abstract}

\section{Keywords}

Vibration, resonance, shock absorber, vibration transport and technological machines.

\section{Introduction}

The majority of vibration transport and technological machines (VTTMs) such as conveyors, screens, crushers, vibratory plates, etc. operate above resonance (Bauman and Bykhovsky, 1977; Kuzmichev, 2014). Resonance occurs when oscillations of a vibration machine start or stop. This phenomenon is accompanied by sharply rising values of the amplitude and velocity of oscillations. Resonance affects VTTM operation adversely: dynamic loads on the machine components increase, excess noise occurs, machinery operating life and reliability are reduced (Chelomey, 1981).

Machinery protection against the destructive effect of resonant amplitudes and increased vibration loads is a challenging issue and a top priority in VTTM design. There are various solutions available for damping resonant amplitudes. One of the most effective solutions is the use of telescopic hydro-pneumatic shock absorbers (Derbaremdiker, 1969; Dobromirov et al., 2006, Repin et al., 2020; Rotenberg, 1972) that were already tried and tested (in motor vehicles). In such hydro-pneumatic shock absorbers, the resistance coefficient changes in proportion to the velocity of oscillations.

\section{Methods}

This study focuses on oscillatory processes in VTTMs. The purpose of the study is to provide a theoretical substantiation for the possibility to design such mechanical devices as automotive shock absorbers for oscillatory process control and develop an example of practical implementation for such a device.

The proposed method of controlling oscillatory processes in VTTMs lies in the use of dualmode shock absorbers. In the operating mode, shock absorbers shall offer minimum resistance to oscillatory motion. In the resonance mode, resistance shall increase in order to decrease the amplitude to a predetermined value.

Shock absorbers used in motor vehicles operate in two modes: throttle and valve ones (Demić and Diligenski, 2016; Dobromirov et al., 2006; Hrovat and Hubbard, 1982; Repin et al., 2020; Sani et al., 
2008). At small amplitudes and, consequently, low velocities, the valves are closed, and the liquid is forced through the throttle channels in the piston. That is the throttle mode. With an increase in piston velocity, hydraulic resistance to its motion increases as well, and the valves open, reducing the resistance. That is the valve mode.

The damping force generated by such a shock absorber is as follows (Dobromirov et al., 2006; Repin et al., 2020; Rotenberg, 1972):

$$
P d=k \times v^{i}
$$

where $k$ - resistance coefficient of the hydropneumatic shock absorber; $v$ - velocity of vertical VTTM motion; $i$ - power index.

The shock absorber characteristic may vary depending on the power $i$ :

1) linear (at $i=1.0$ );

2) progressive (at $i>1$ )

3 ) regressive (at $i<1)$.

Its type depends directly on the shock absorber design parameters. The coefficients $k$ (compression stage) and $k_{e}$ (extension stage) have different values. Figure 1 presents a progressive characteristic curve, which most corresponds to the specified conditions. This is a schematic representation since the actual characteristic curve will be nonlinear (shown by the dashed line).

However, due to their parameters, industrial shock absorbers cannot be used in VTTMs. The working stroke (amplitude of oscillations) in VTTMs, corresponding to the throttle mode, is $1-10 \mathrm{~mm}$, while in industrial shock absorbers, it is by an order of magnitude greater. Besides, the damping value in the throttle mode is too high, at least tens of newtons, which leads to increased energy consumption per vibration process.

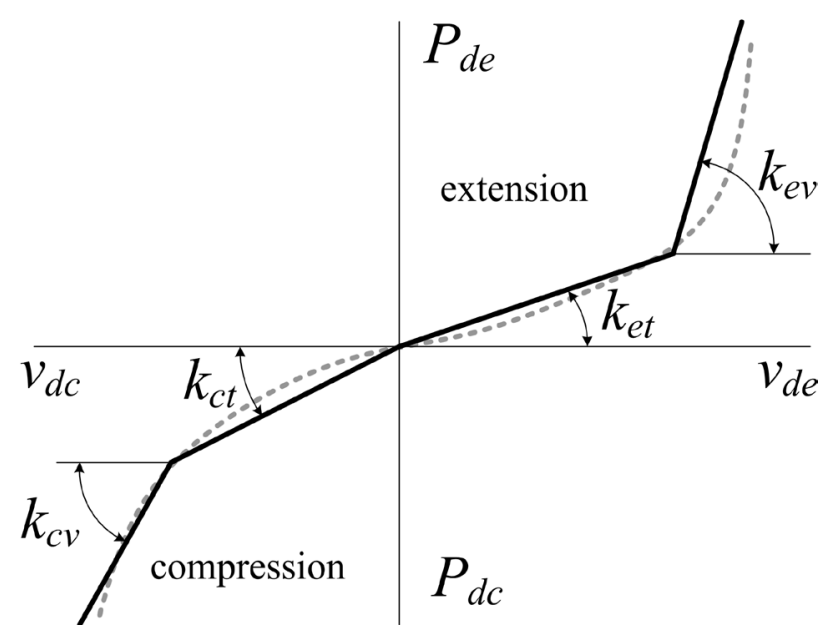

Figure 1. Shock absorber characteristic curve: $P_{d}$ - damping force; $v_{d}$ - piston velocity; $k$ - resistance coefficient; subscripts: $c$ - compression; $e$ - extension; $t$ - throttle mode; $v$ - valve mode
Therefore, it is required to develop a new shock absorber design, which would satisfy VTTM operating conditions to the fullest extent possible.

\section{Results}

Let us describe a method to substantiate the selection of hydro-pneumatic shock absorbers' parameters by means of simulating VTTM operation (Fig. 2).

The VTTM comprises housing 1 with the material and is driven by vibrator 2 generating directed oscillations. The VTTM is located on base plate 5 , on four hydraulic shock absorbers 3 and four springs 4 .

The forces acting on the VTTM can be described by the following equation (Kuzmichev, 2014):

$$
P_{i}+P_{s}+P_{d}+G=F(t),
$$

where $P_{i}$ - inertia; $P_{s}$ - spring force; $P_{d}$ - damping force of the hydraulic shock absorbers; $G$ - VTTM weight; $F(t)$ - external impact.

The force $F(t)$ created by the vibrator generating directed oscillations changes with time according to the following law (Bauman and Bykhovsky, 1977):

$$
F(t)=F_{0} \times \cos (\Omega t),
$$

where $F_{0}$ - amplitude of the disturbing force of the vibrator generating directed oscillations; $t$ - time, s; $\Omega$ - frequency of the vibrator generating directed oscillations, $\mathrm{s}^{-1}$.

Using the equation, we can determine the restoring force of a vibration conveyor spring (Dobromirov et al., 2006; Repin et al., 2020):

$$
P_{s}=-l \times c,
$$

where $l$ - spring travel during operation; $c$ - spring stiffness, N/m.

Using this equation, we can find the damping force of the shock absorber, affecting the conveyor:

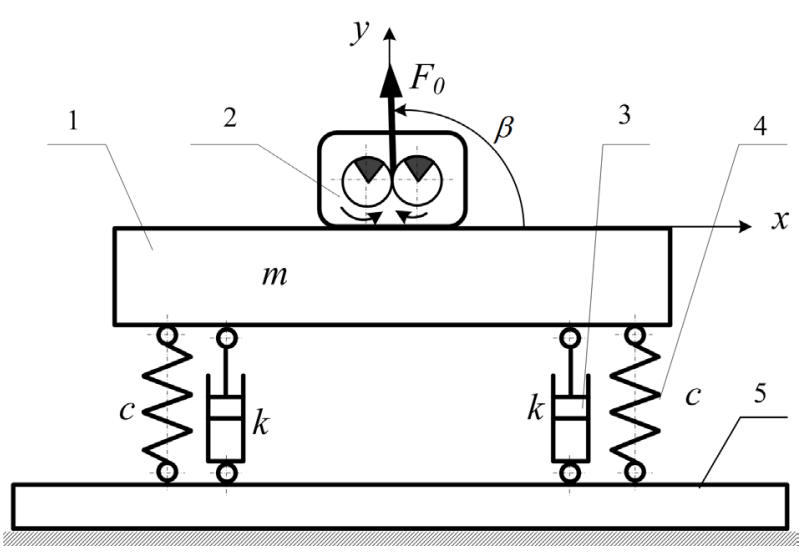

Figure 2. VTTM design model:

1 - VTTM housing; 2 - vibrator generating directed oscillations; 3 - shock absorbers; 4 - springs; 5 - base plate; $m$ - VTTM weight with the material being moved; $\beta$ - angle of the disturbing force 


$$
P_{d}=-k \times v,
$$

where $v$ - velocity of the piston with the piston rod, $\mathrm{m} / \mathrm{s} ; k$ - resistance coefficient of the hydraulic shock absorber, Ns/m (Newton per second/meter).

Newton's Second Law can be written as follows (Kuzmichev, 2014):

$$
m \times a=-c \times l-k \times v+F(t),
$$

This equation describes a plane case and small forced oscillations (Chelomey, 1981); in the differential form, the equation of vibration conveyor motion will be as follows (Kuzmichev, 2014; Repin et al., 2020):

$$
m \times y(t)+2 \times c \times y(t)+2 \times k \times y(y)=F(t),(7)
$$

where $y$ - value of movement along the $y$ axis.

The angle of the disturbing force and the angles of the shock absorber axes are taken identical to simplify the mathematical model. Therefore, we cancel their trigonometric functions in the equation.

As a result, equation (7) can be written in the following form:

$$
\ddot{y}(t)+\omega_{0}^{2} \times y(t)+h \times \dot{y}(t)=\frac{F(t)}{m},
$$

where $h=k /(2 \times m)$ - damping coefficient, $\mathrm{N} \cdot \mathrm{s} /$ $(\mathrm{kg} \cdot \mathrm{m}) ; \omega_{0}=(2 \times c / m)^{1 / 2}$ — eigen frequency of the conveyor, $\mathrm{s}^{-1}$.

The amplitude of steady-state oscillations can be determined using the following equation (Demić and Diligenski, 2016):

$$
A_{\mathrm{op}}=F_{0} /\left(m \times \sqrt{\left(\Omega^{2}-\omega_{0}^{2}\right)^{2}+4 \times h^{2} \times \Omega^{2}}\right) .
$$

The angular frequency $\Omega_{0}=\sqrt{\omega_{0}^{2}-2 \times h^{2}}$ matches the maximum value of the amplitude $A_{\max }$. The angular frequency is slightly less than the eigen angular frequency of the vibration system $\Omega=\sqrt{\omega_{0}^{2}-h^{2}}$

$$
A_{\max }=F_{0} /\left(2 \times h \times m \times \Omega_{0}\right) .
$$

An increase in the shock absorber damping coefficient $\mathrm{h}$ will lead to a decrease in the maximum oscillation amplitude $A_{\max }$ and straightening of the resonant oscillations' curves $A(\Omega)$, which will make it possible to significantly reduce the phenomenon of resonant oscillations. At $h \geq \omega_{0} / \sqrt{2}$, resonant oscillations disappear completely (Chelomey, 1981).

Figure 3 presents the result of resonant amplitude calculation depending on the shock absorber resistance coefficient in Mathcad. Based on this calculation, the actual values of the damping coefficient $h$ and the shock absorber resistance coefficient $k$ are derived. An example of calculation for a test bench, performed in Mathcad, shows that the resistance coefficient should be not less than $2000 \mathrm{~N} \cdot \mathrm{s} / \mathrm{m}$ to limit the maximum amplitude in the amount of $0.01 \mathrm{~m}$. This is the maximum resistance to be developed by the shock absorber.

Then, based on the found characteristics of oscillations' damping, we selected parameters of the hydraulic shock absorber. In addition to that, we developed several shock absorber designs meeting the condition. The design (Fig. 4) obtained by utility model modernization (Repin and Litvin, 2017) is the most promising. Shock absorber resistance is found using the ratio between the values of amplitude oscillations and the values of piston travel $l$ in the piston chamber. At a lesser amplitude $l$, there is a flow of liquid through the gap $\delta_{r s}=\left(d_{s}-d_{r}\right) / 2$ between the rod and the sleeve. At a higher amplitude $I$, there is a flow of liquid through the gap $\delta_{p s}=\left(d_{s}-d\right) / 2$ between the piston and the sleeve, which is significantly less than the gap described above. Therefore, in case of a higher amplitude, resistance to fluid flow is higher as well, which means that the shock absorber resistance coefficient is also higher.

The shock absorber operates as follows: the device is installed between the main and the oscillating parts of the vibration machine. In the operating mode, piston parts 3 and 5 move outside hydraulic sleeve 4 . Therefore, the operating (steadystate) amplitude value $A_{\text {op }}$ is less than the gap value $l$. Thus, in this operating mode, resistance to movement of two-point rod 2 includes the following forces: the rod friction force (in the point of contact with cylinder housing 1), the force of hydraulic friction in the moving parts inside the shock absorber, as well as the inertia of the moving parts of the shock absorber, such as the hydraulic piston and two-point rod. In this mode, the resistance coefficient of the hydraulic shock absorber is minimal.

In case of resonant oscillations when the amplitude exceeds the value of $l$, hydraulic pistons 3 and 5 will enter the internal cavity of sleeve 4 . This

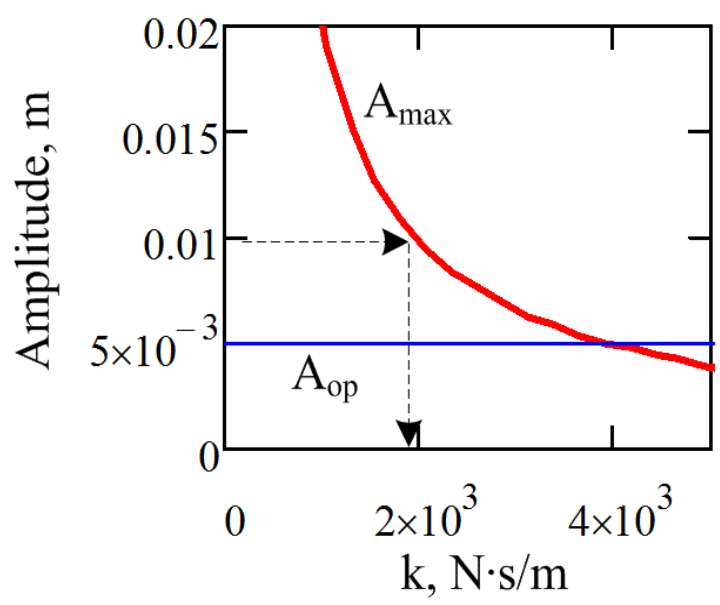

Figure 3. Dependence of the resonant amplitude of oscillations $A_{\max }$ in a VTTM on the shock absorber resistance coefficient 
will cause a sharp increase in hydraulic resistance due to shock absorber liquid pushing through the gaps between sleeve 4 and hydraulic pistons 3 and 5. The resistance coefficient of the shock absorber will increase proportionately, and the amplitude of oscillations will decrease correspondingly.

Pin bush 6 is required in order to stabilize the movement of two-point rod 2 strictly along the axis of cylinder 1 . Since the gap between the central hole of sleeve 6 and two-point rod 2 is quite large, there will be no friction between them. Holes in sleeve 6 allow the liquid to move freely inside hydraulic cylinder 1 of the hydraulic shock absorber.

During movement of two-point rod 2, compensating gas piston 7 counterbalances the changes in the internal volume of cavity $B$ filled with liquid.

When developing a mathematical model of shock absorber operation, alternating processes of expansion and compression during the operation of the hydraulic shock absorber are taken into account.

At the compression stage, all energy from external forces is directed at overcoming the friction forces $P_{\mathrm{f}}$ in the shock absorber gaskets, at compressing gas $P_{\mathrm{g}}$ in the gas cavity, pushing liquid $P_{l}$ through the gap between the sleeve and the two-point rod with the hydraulic piston, overcoming the gravity force $G_{g}$

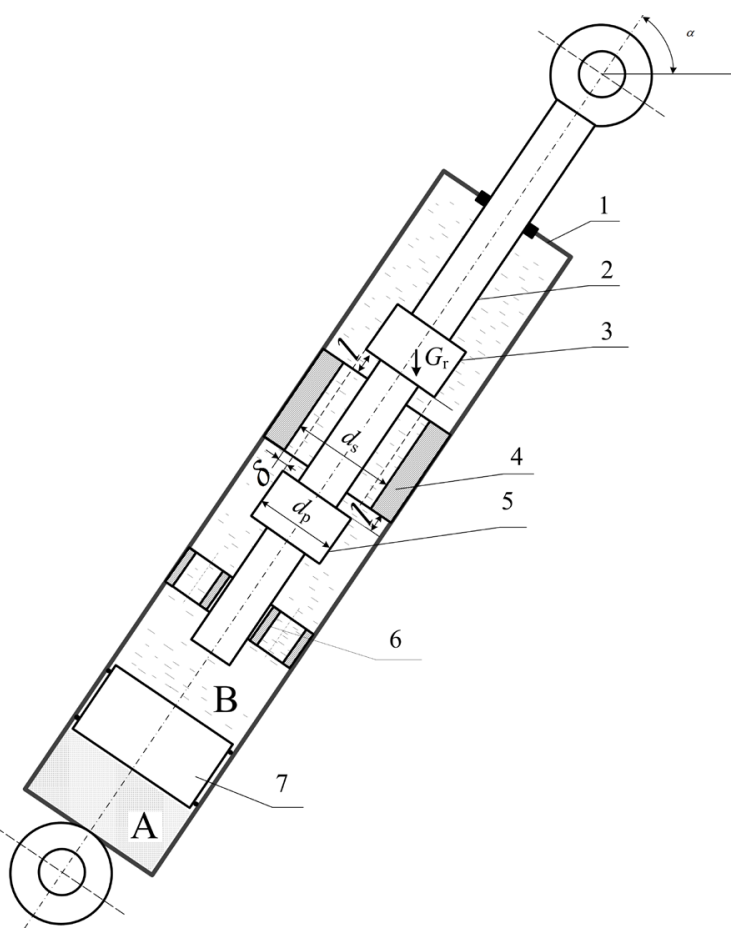

Figure 4. Shock absorber of resonant oscillations: 1 - cylinder housing; 2 - two-point rod; 3, 5 - hydraulic piston; 4 - sleeve; 6 - pin bush; 7 - compensating gas piston; A - cavity filled with gas; B — cavity filled with liquid; $G_{r}-$ gravity force of the rod with the hydraulic piston; $d_{\mathrm{s}}-$ sleeve diameter; $d_{\mathrm{p}}$ - piston diameter; $\delta$ - gap between the two-point rod and the sleeve; $I$ - distance from the sleeve to the hydraulic piston; $\alpha$ - shock absorber installation angle and inertia $P_{\mathrm{i}}$ of the moving two-point rod with the hydraulic piston:

$$
P_{C}=P_{g}+P_{l}+P_{f}+P_{i}-G_{\mathrm{g}} \cos \alpha .
$$

At the expansion stage, the force in the shock absorber is as follows:

$$
P_{E}=P_{g}+P_{l}+P_{f}+P_{i}+G_{\mathrm{g}} \cos \alpha .
$$

The main difference between the presented shock absorber for damping of resonant oscillations and standard automotive shock absorbers is that there are different values of resistance $P_{1}$ to liquid pushing through the different gaps in the shock absorber: liquid movement through the gaps between the sleeve and the rod has small resistance while its movement through the gaps between the sleeve and the piston has quite significant resistance. Therefore, it is the latter that has the most impact on the final characteristic of a hydraulic shock absorber. According to the mathematical calculations related to the hydraulics (Dalin and Mikheev, 2001), the value of resistance to movement of the hydraulic piston in the sleeve is expressed through resistance to movement of liquid through the described gaps between the sleeve and the two-point rod with the hydraulic piston:

a) if the amplitude of oscillations is less than the distance $l$, liquid flows through the gap between the sleeve and the rod

$$
P_{l 1}=\frac{\rho_{l} \times v_{p}^{2} \times F_{p}^{2}}{2 \times g \times \mu^{2} \times S_{r s}^{2}} .
$$

b) if the amplitude of oscillations is more than the distance I, liquid flows through the gap between the sleeve and the piston

$$
P_{l 2}=\frac{\rho_{l} \times v_{p}^{2} \times F_{p}^{2}}{2 \times g \times \mu^{2} \times S_{p s}^{2}},
$$

where $\rho_{l}$ - liquid density; $F_{\mathrm{p}}$ - area of the hydraulic piston; $S_{\mathrm{rs}}$ and $S_{\mathrm{ps}}$ - area of the gap between the twopoint rod and the sleeve; area between the hydraulic piston and the sleeve; $v_{\mathrm{p}}$ - hydraulic piston velocity; $\mu$ - leakage coefficient that depends on the liquid viscosity and the size of the gaps (0.65-0.75).

The relationships between the effective area of the hydraulic piston and the gap area are as follows:

a) at downwards movement

$$
\begin{gathered}
F_{p \downarrow}=\pi \times d_{\mathrm{p}}^{2} / 4 . \\
S_{p s}=\pi \frac{\left(d_{s}^{2}-d_{r}^{2}\right)}{4} .
\end{gathered}
$$

b) at upwards movement 


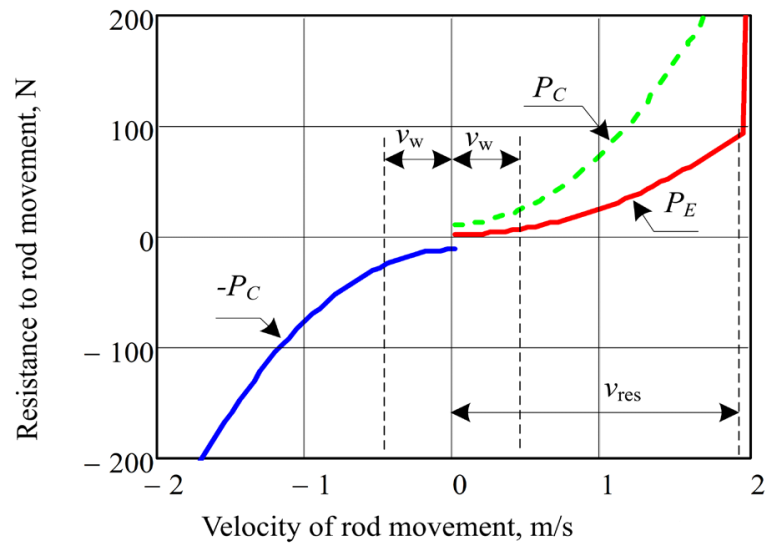

Figure 5. Hydraulic shock absorber characteristic: $v_{\text {res }}$ - rod velocity when entering the resonance mode; $v_{w}$ — rod velocity in the VTTM working mode (when the axis of oscillation is crossed)

$$
\begin{gathered}
F_{p \uparrow}=\pi\left(d_{p}^{2}-d_{r}^{2}\right) / 4 . \\
S_{p s}=\pi \frac{\left(d_{s}^{2}-d_{r}^{2}\right)}{4} .
\end{gathered}
$$

Figure 5 shows the shock absorber characteristic simulated in Mathcad.

As seen from the diagram of the hydraulic shock absorber characteristic, the resonant velocity is limited to the resistance of the hydraulic shock absorber. It is clearly seen in the $P_{E}$ curve. When the hydraulic shock absorber enters the internal space of the sleeve, a sharp increase in the force $P_{E}$ occurs. The hydraulic shock absorber slows down the oscillatory process and, thus, limits the amplitude of oscillations.

Figure 6 shows a combination of the operating characteristics of a vibration transport and technological machine (Fig. 3) and the developed hydraulic shock absorber. This makes it possible to choose not only the required values of the shock absorber resistance coefficient in two modes (working and resonance modes) but also the required design characteristics of the hydraulic shock absorber such as: the size of the hydraulic pistons, the two-point rod, and the sleeve, as well as pressure in the gas chamber.

\section{Discussion}

Thus, through the theoretical study of the

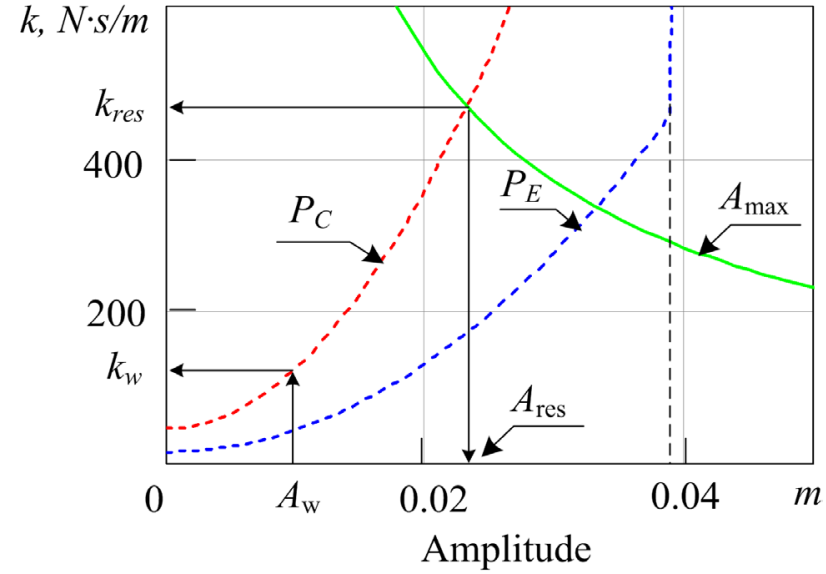

Figure 6. Dependence between the shock absorber resistance coefficient and the VTTM amplitude of oscillations: $A_{\text {res }}$ - resonant amplitude;

$A_{\mathrm{w}}$ - working amplitude of oscillations

operation of the proposed shock absorber, we have shown that such devices can be applied in vibration transport and technological machines. Being able to operate in two modes (with a small and high resistance coefficient), the shock absorber virtually does not impede the oscillatory process in the steady-state mode of operation and, also, actively dampens resonant oscillations in transient modes.

\section{Conclusion}

In the course of the study, we performed the mathematical simulation of the oscillatory process in a vibration transport and technological machine with the installed damping device. We derived the mathematical expression for the damping coefficient, which ensures damping of resonant oscillations.

The new design of the VTTM hydraulic shock absorber was described. This design offers the minimum resistance in the operating mode and the required resistance upon the occurrence of resonant oscillations.

We also developed the mathematical model for the joint operation of the hydraulic shock absorber and a VTTM. The model was implemented in the Mathcad environment. The combination of the operating characteristics of the hydraulic shock absorber and a VTTM makes it possible to select the required parameters of the shock absorber resistance coefficient in the working and resonance modes. Besides, using this combination, we can choose the values of design characteristics for the hydraulic shock absorber in order to damp resonantoscillations. 


\section{References}

Bauman, V. A. and Bykhovsky, I. I. (1977). Vibration machines and processes in construction. Moscow: Vysshaya Shkola, $255 \mathrm{p}$.

Chelomey, V. N. (ed.) (1981). Vibration in engineering. Reference book in 6 volumes. Vol. 1. Moscow: Mashinostroyeniye, $352 \mathrm{p}$.

Dalin, V. N. and Mikheev, S. V. (2001). Design of helicopters: textbook. Moscow: Publishing House of the Moscow Aviation Institute, $352 \mathrm{p}$.

Demić, M. D. and Diligenski, D. M. (2016). Numerical simulation of shock absorbers heat load for semi-active vehicle suspension system. Thermal Science, 20 (5), pp. 1725-1739. DOI: 10.2298/TSCI150624005D.

Derbaremdiker, A. D. (1969). Hydraulic shock absorbers of motor vehicles. Moscow: Mashinostroyeniye, 236 p.

Dobromirov, V. N., Gusev, E. N., Karunin, M. A. and Khavkhanov, V. P. (2006). Shock absorbers. Design. Calculation. Testing. Moscow: Moscow State Technical University «MAMI», 184 p.

Hrovat, D. and Hubbard, M. (1982). Optimum vehicle suspensions minimizing RMS ratllespace, sprung mass, and jerk. ASME, paper No. 81-WA/DSC-23.

Kuzmichev, V. A. (2014). Fundamentals of vibration equipment design. Study guide. Saint Petersburg: Lan Publishing House, $208 \mathrm{p}$.

Repin, S., Bukirov, R. and Vasilieva, P. (2020). Study on effects of damping characteristics of base chassis suspension on operational safety of transport and handling machinery. Transportation Research Procedia, Vol. 50, pp. 574-581. DOI: 10.1016/j.trpro.2020.10.069.

Repin, S. V., Dobromirov, V. N., Orlov, D. S. and Andronov, A. V. (2020). Research of the elastic characteristics of the new hydropneumatic shock absorber. Bulletin of Civil Engineers, No. 2 (79), pp. 187-194.

Repin, S. V. and Litvin, R. A. (2017). Shock absorber for extinguishing resonance vibrations in vibration machines. Patent No. RU170565U1.

Rotenberg, R. V. (1972). Motor vehicle suspension. Vibrations and running smoothness. $3^{\text {rd }}$ edition. Moscow: Mashinostroyeniye, $392 \mathrm{p}$.

Sani, M. S. M., Husin, E. and Nor, M. M. (2008). Experimental heat transfer study on the shock absorber operation. In: International Conference on Science \& Technology: Applications in Industry \& Education, December 12-13, 2008, Permatang Pauh, Penang, Malaysia, pp. 759-765. 


\title{
ПРИМЕНЕНИЕ АМОРТИЗАТОРОВ АВТОМОБИЛЬНОГО ТИПА ДЛЯ ДЕМПФИРОВАНИЯ РЕЗОНАНСНЫХ КОЛЕБАНИЙ В ТЕХНОЛОГИЧЕСКИХ МАШИНАХ
}

\author{
Сергей Васильевич Репин ${ }^{1}$, Роман Андреевич Литвин ${ }^{1 *}$, Виктор Алексеевич Кузьмичёв ${ }^{2}$, \\ Иван Иванович Воронцов ${ }^{1}$ \\ ${ }^{1}$ Санкт-Петербургский государственный архитектурно-строительный университет \\ 2-ая Красноармейская ул., 4, Санкт-Петербург, Россия \\ ${ }^{2}$ Санкт-Петербургский политехнический университет Петра Великого \\ ул. Политехническая, 29, Санкт-Петербург, Россия \\ *E-mail: roman.Itv@mail.ru
}

\begin{abstract}
Аннотация
Многие вибрационные транспортно-технологические машины (ВТТМ) - транспортеры, грохоты, дробилки и другие, работают в высокочастотном режиме, называемом зарезонансным. Явление резонанса возникает в периоды запуска и торможения машины, что вызывает резко-возрастающие значения амплитуды и скорости колебаний. На работе ВТТМ явление резонанса сказывается крайне негативно, ввиду повышения динамических нагрузок, которые снижают ресурс и надежность машины, вызывают шум. Цель исследования: Теоретическое обоснование возможности применения амортизаторов автомобильного типа для управления колебательным процессом ВТТМ и разработка примера практической реализации такого устройства. Метод: Метод управления колебательными процессами в ВТТМ заключается в использовании двухрежимных амортизаторов. В рабочем режиме амортизаторы создают минимальное сопротивление движению. В резонансном режиме сопротивление увеличивается, поэтому амплитуда снижается до заданного значения. Результаты: В статье выполнено моделирование колебательного процесса ВТТМ с целью определения характеристик демпфирующего устройства, обеспечивающего гашение резонансных колебаний и, в то же время, не влияющего на рабочий вибрационный процесс. Предложено новое техническое устройство, реализующее требуемые характеристики колебаний. Устройство выполнено в виде гидропневматического амортизатора, подобного по конструкции автомобильным амортизаторам. Особенность конструкции разработанного амортизатора позволяет обеспечить незначительное сопротивление полезной (рабочей) вибрации машины, но в то же время сопротивление амортизатора значительно увеличивается при возникновении резонансных амплитуд. Оригинальность данного исследования заключается в разработке нового вида гидравлического амортизатора, на конструкцию которого получен патент на полезную модель. Научная новизна заключается в математическом описании процесса демпфирования колебаний новым амортизатором, в разработке компьютерной программы расчета колебательного процесса по разработанной математической модели, в результатах компьютерного моделирования работы амортизатора.
\end{abstract}

\section{Ключевые слова}

Вибрация, резонанс, амортизатор, вибрационные транспортно-технологические машины. 